\title{
Quality of life (QOL) and depression in HTLV-1 carriers
}

\author{
Ana V Galvão-Phileto*, Ney Boa-Sorte, Ramon A Kruschewsky, Bernardo Galvão-Castro* \\ From 15th International Conference on Human Retroviruses: HTLV and Related Viruses \\ Leuven and Gembloux, Belgium. 5-8 June 2011
}

\section{Background}

The prevalence of depression in HTLV-1 infected patients is about $30 \%$. However, there are few studies about depression and QOL in patients infected with HTLV-1. The aim of this study is to verify the association between depression and predictors of QOL of people living with HTLV-1.

\section{Material and methods}

A cross-sectional study was carried out from March to November, 2009 in Salvador, Brazil. The instruments used were a questionnaire for the collection of clinical and epidemiological data, the Mini International Neuropsychiatric Interview, Brazilian Version 5.0.0 (M.I.N.I.) to estimate the rate of depression and the short version of the WHO quality of life scale (WHOQOL-BREF).

\section{Results}

The overall prevalence of depression was $34.7 \%$ (33out 95). Depression was significantly associated with poorer QOL in physical, psychological "social relationship" and environment domains.

\section{Conclusion}

This study confirms the high prevalence of depression in individuals infected with HTLV-1. It also shows that depression significantly affected the QOL of these individuals. Since treating depression could improve the QOL, we strongly recommend early identification and referral of patients with depression. This measure should be included into intervention programs designed for individuals infected HTLV-1.

* Correspondence: bgalvao@bahiana.edu.br

Centro de HTLV, Escola Bahiana de Medicina e Saúde Pública, Salvador, Bahia, Brasil
Published: 6 June 2011

doi:10.1186/1742-4690-8-S1-A65

Cite this article as: Galvão-Phileto et al.: Quality of life (QOL) and depression in HTLV-1 carriers. Retrovirology 2011 8(Suppl 1):A65.
Submit your next manuscript to BioMed Central and take full advantage of:

- Convenient online submission

- Thorough peer review

- No space constraints or color figure charges

- Immediate publication on acceptance

- Inclusion in PubMed, CAS, Scopus and Google Scholar

- Research which is freely available for redistribution

Submit your manuscript at www.biomedcentral.com/submit
() Biomed Central 